\title{
Az erdélyi Bálványos-fürdőről
}

\author{
Gömör Béla dr.
}

\begin{abstract}
Semmelweis Egyetem, Általános Orvostudományi Kar, a III. Belgyógyászati Klinika Reumatológiai és Fizioterápiás I. Tanszéki Csoportja a Budai Irgalmasrendi Kórház telephelyén, Budapest
\end{abstract}

Az orvostörténeti írások közül talán a balneológiai tárgyúak a legszínesebbek, legváltozatosabbak. Ezek ugyanis nemcsak személyek, intézmények statikus leírását adják közre, hanem a témából fakadóan - az orvosi vonatkozásokon túl - történelmi, földrajzi, geológiai, sőt szociális hátteret is fölfestenek.

Álljon itt kerettörténetként a következő. 2018 júniusában a balneológia iránt érdeklődő 12 -es csoportunk már második alkalommal tett erdélyi körutazást. Ennek során meglátogattuk a bálványosi terület Csiszár-fürdőjét, ahol részletes tájékoztatást nyertünk a mai tulajdonosoktól. Így érdemesnek tűnt felkutatni eredeti irodalmi forrásokat, hogy azok alapján ennek a szinte egzotikus helynek a gazdag múltját föl lehessen vázolni, és össze lehessen vetni a jelen helyzettel.

Bálványos vidéke a Székelyföld legtávolabbi részén található, Erdély délkeleti régiójában, az Olt völgyétől keletre, az 1876-ban létesült Háromszék megyében. Más kérdés, hogy közigazgatási változások miatt 1968 óta Kovászna megyében találjuk. Itt van a Keleti-Kárpátok hegyvonulatának legdélebbi pólusa, ahol gazdagon lelhetők föl az utóvulkáni múködések jelei.

Kétségtelen, hogy újkori történetünkben a Bálványos név azért lett közismert, mert 1989-től itt tartják a Nyári Szabadegyetem rendezvényeit.

Orbán Balázs (1829-1890) a hatkötetes múvében két fejezetet is szentel e tájnak [1]. Neki aztán lehet hinni, hiszen személyes gyưjtőútján nyert tapasztalatait foglalta össze ebben a gigantikus munkában. A székely krónika szerint az ősi pogány vallás tiszteletének fönntartására a várat Opour vezér építtette az 1056 méter magasan fekvő, cukorsüveg alakú hegyormon.

Fény derült azonban arra, hogy az előző műnél előbb - igaz, francia nyelven - egy útinapló már leírta a várat, sőt a Büdös-barlangot (lásd később) is. Minderról a nemrég kiadott magyar fordításból lehet értesülni [2].

Nagy mesélőnk, Jókai Mór pedig Bálványosvár címú regényében állított emléket e helynek, ahol a legtovább áldoztak az ősvallásnak, de „A pokol tornáca” fejezetben említést tesz a Büdös-barlangról is.

A várat és környékét a 20. század elejéig birtokló Apor család az ezer évvel ezelőtti építtetőre vezeti vissza eredetét. A 17. század eleje óta a várnak csak a romjai láthatók, a bárói család pedig torjai kastélyában lakott.
A természet errefelé igencsak bőven fakasztotta a különlegesen gazdag ásványvizeket. Sok helyen a földből tör föl a buborékos víz, melyet Erdélyben borvíznek neveztek el. Az elnevezés alapja, hogy ezek fogyasztása a gazdag szénsavtartalom miatt olyan illúziót kelt, mintha bort inna valaki. Empirikus alapon kiterjedten használták gyomorbajokra. Másrészről ott van az 1153 méter magasan található, híres torjai Büdös-barlang, ez a 14 méter mély üreg, amelyet Európa legnagyobb természetes mofettájaként tartanak számon. A hegy a barlangon keresztül igen magas koncentrációban leheli ki kénes gőzeit. A gáz leülepszik, de ha az emlősök a szintje alá kerülnek, a fulladásukat okozza. „A kénbarlangban csak pár lélegzetet kell venniök, $s$ az elviselhetetlen élet megsemmisült.” A sárga lepellel bevont falak közé „A betegek, fóként a szemfájósak és köszvényesek seregesen jönnek ide, felmásznak e meredek hegy barlangjához" [1]. Ugyanis a barlang alján levő kőrétegek lecsepegő vizét összegyưjtötték, és azzal mosogatva a szemet, egyes bajok ellen hatásos gyógyszernek bizonyult. A Büdös-barlangról írásos emlék már 1344-ből származik, mégpedig egy peres irat formájában [3].

A harmadik kincs errefelé a timsós víz. Ezek káliumalumínium-timsót tartalmaznak, s kémiai felépítésüket tekintve kettős szulfátok. A szénsavas és kénes vizek létrejöttét vulkanikus utóhatásoknak értékelik. Ehelyütt a kénföldet és a timsót bányászták is. Ezért bírt Torja [ma Turia] mint bányászhelység országgyúlési képviselettel.

A terület ásványvízgazdagsága régen ismert lehetett, hiszen Orbán Balázs így ír: „A Büdös aljában van a Bivaly feredō borvize, mely legjobba vidéken, s jóságban és erőben a borszékivel mérközik." Ötőle tudhatjuk meg azt is, hogy a Büdös-hegy tövén olyan ásványos vizet fedeztek föl, amelynek az 1865-ben elvégzett analízise szerint a szilárdalkatrész-tartalma literenként 27,2161 gramm volt, míg a szénsavtartalma 1,2383 grammnak bizonyult.

Folytatásként, még a két évtizeddel későbbi, alapos tudományos balneológiai összefoglaló kötet sem szól Bálványosról, hanem „Büdös”-fürdőként említi a nyolc forrást (köztük a Katalin-, a Károly- és a Borvíz-forrást). Az alpári viszonyokat szemlélteti a hiteles leírás: „A források közelében vályogból és deszkából összetákolt, istálló kinézésu" 4-5 ház áll, ezek a lakóbázak Tölïk néhány lépésnyive van 


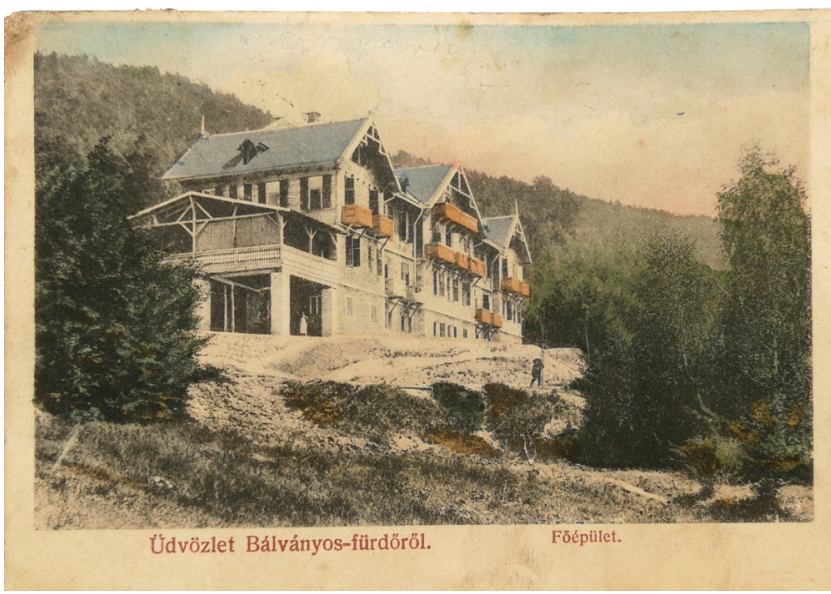

1. ábra

Az 1895-ben épült fürdőintézmény egykori képeslapon. Dr. Jakó János tulajdona

a fürdőház deszkákból összetákolva, ebben két lobogófürdó van s több fürdökabin fakádakkal ellátva” [4].

Báró Apor Gábor (1851-1898) politikus, államtitkár a család ősi birtokán, a torjai Büdös-barlang alatt 1895ben alapította meg Bálványosfürdőt (románul Băile Bálványos, németül Bad Götzenburg). Neje, Pálffy Fidelis grófnő korábban a makacs gyomorbaja ellen hiába keresett gyógyulást a világhírü fürdőhelyeken, végezetül itt, a birtokon talált forrás vize gyógyította meg. Nagyban föltételezhető, hogy a kellemetlen savhiányos állapotot sikerült a szénsavban gazdag természetes vízzel eredményesen kikúrálni. Ezért kapta hálából az egyik forrás a Fidelis-forrás nevet. Sőt voltak, akik később az egész területet Fidelis-fürdőnek nevezték. A báró - a bőséges források lehetőségét kihasználva - az akkori kor minden igényét kielégítő 50 szobás, kétemeletes gyógyintézetet építtetett a Sósmezőnek nevezett fennsíkon (1. ábra). Az üdülőhelyi szállodában a hideg vizes kezelések Wilhelm Winternitz (1835-1917) cseh-osztrák vízgyógyász specialista elvei szerint múködtek. A szanatóriumhoz orvosi rendelő, gyógyszertár, könyvtár, vendéglö, teniszés tekepálya is tartozott.

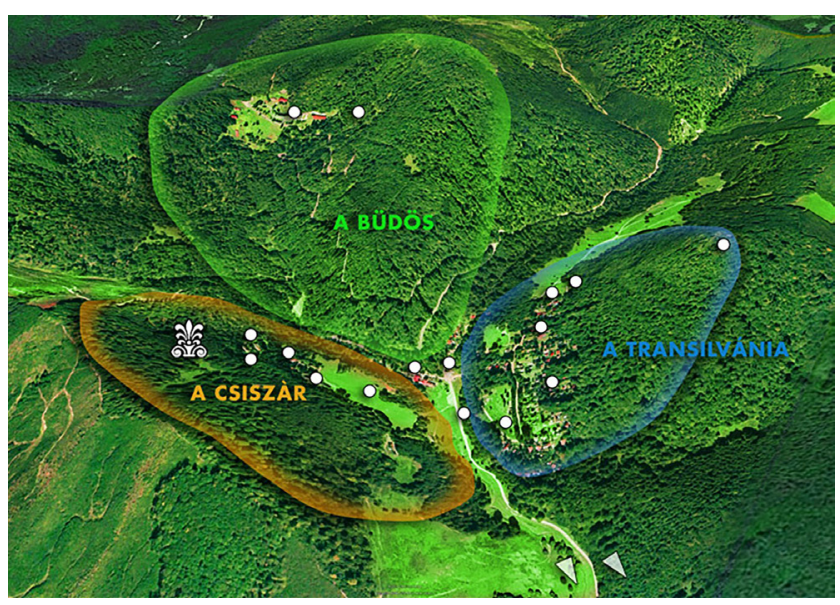

2. ábra

| A három fürdőterületet érzékeltető térkép
A megnyitásról szóló sajtóbeszámolóban megemlítik, hogy a belügyminisztérium osztálytanácsosa, Chyzer Kornél (1836-1909 ) - aki az egész ország közegészségügyéért volt felelős - álmélkodott azon a nagy változáson, amelyet a megnyíló Bálványosfürdőn észlelt. Korábban itt ázsiai állapotokat talált, most pedig a gyönyörú környezetben felépített új intézmény okán már reménykedni lehet, „e hely megérdemelten világhirüvé válhat” [5].

Értelemszerűen a „Magyar Sz. Korona Országai Balneológiai Egyesülete” komoly szakmai összegző kiadványa már három oldalt szentelt Bálványosfürdőnek [6].

A fürdőteleppel foglalkozó írások több mint egy évszázadon át váltogatták a fürdő és a füred elnevezést. Az 1941-ben idelátogató budapesti balneológusok (1. később) is megpróbáltak különbséget tenni: „Zavart okoz a fürdök többféle elnevezése is. Igy ... Bálványos-fürdö neve Torja-fürdö, de van egy Bálványosvár-fürdö, vagy Bálványosfüred is" [7]. Ma Bálványosfürdőn egyértelmüen a három régi és egykoron múködő fürdőtelep együttesét értjük.

A hegyes-völgyes tájakra jellemzően egy idegennek kissé nehéz eligazodni a területen. A 2. ábra szemlélteti a viszonyokat. Mind a három hegyoldalon találhatók források, amelyek kisebb-nagyobb fürdőket képeznek.

Lexikoni meghatározás szerint a Büdös-hegy nyúlványán elterülő telep, Bálványosfürdő az 1910-es népszámlálás szerint 14 lakossal rendelkezett [8]. Ugyanitt szerepel a kijelentés: „Karatnavolálhoz tartozó fürdo"hely." Ez a helységnév már nem létezik, mert a későbbiekben egybeépült Torjával, ahol a neves altorjai Aporkastély található. A legközelebbi vasútállomás neve a magyar időkben Sepsibükszád-Bálványosfüred volt, egyértelmúen utalva arra, hogy ez volt a fürdő megközelítésének fő lehetősége. Innen 14 kilométeren át egykoron förtelmesnek leírt út vezetett a fürdőhelyhez, de manapság is hagy maga után kívánnivalót a 131-es autóut. Egyébként a nevezetes turistacélpontok közül a Szent Anna-tó 11 km-re, Tusnádfürdő pedig 18 km-re van Bálványosfürdőtől, míg a legközelebbi nagyobb város a másik irányban 21 km-re Kézdivásárhely (ma Târgu Secuiesc).

A Büdös-barlang alatt 100 méterrel fekvő hegynyúlványon - tehát az első fürdőtelepen - számos ásványvízforrás fakad: van köztük savanyúvíz, vasas savanyúvíz, glaubersós víz és szabad kénsavat tartalmazó víz. Ahogy szokták, a forrásokat elnevezték: az ismertebbek a már említett Fidelis-forrás (konyhasós-alkalikus, vasas, szénsavas), a Károly-forrás és a Rákóczi-forrás, valamint a timsós vizeket fölhasználó Apor lányok feredője. A kénes-szénsavas gőzök erőteljes előtörésének legismertebb helyét, a torjai Büdös-barlangot innen, nehéz kaptató úton, 20-25 perc alatt lehet megközelíteni. Így csak mint természeti érdekesség szerepelhet, gyógyászati jelentősége nincs.

A másik forrásterület a Torja vizétől délre eső hegyoldalban lelhető föl. Itt alakult ki a Csiszár Dénes (1857- 
1939 ) nevét ôrző üdülő- és fürdőtelep. A kézdivásárhelyi szeszgyáros 1895 őszén, egy vadászat alkalmával észrevette a földből felbugyogó borvizet. Megvette a vadászterületet, és három, cserfa keretbe foglalt hideg fürdőt hozott létre. A vendégek számára néhány egyszerú faházat épített, amelyeket - és a medencéket is - bagóért lehetett használni. A felszínközeli vízelőtörések hőmérséklete a magasabb fekvésü helyeken alacsonyabb hőmérsékletú, így az itteni borvizek $7-13{ }^{\circ} \mathrm{C}$-osak. A kezdetektől fennmaradt a "Csokoládés” és „Timsós” medencék elnevezése. A fejlesztések során a szeszgyár egy régi kazánját kihozták a fürdőtelepre, és azzal melegítették föl a bőségesen rendelkezésre álló borvizet. A meleg vizet nagy fakádakba öntötték, és abban folyt a fürdőzés [9]. Nehéz megérteni, hogy a századforduló utáni irodalmi források - így például a megállapodott hangvételű, 1911. évi fürdőkataszter is - a Bálványos név alatt miért szól csak a barlang alatti rész remek természeti adottságairól és az 50 ágyas intézményről - de a már több mint egy évtizede múködő Csiszár-fürdőről egy szót sem [10].

A Bálványos-hegy körül múködő harmadik fürdőterület a Transylvania-fürdő. A Vár-hegy lábánál található, régi nevén Várpadi-feredő azért kapta ezt az új nevet, mert a két világháború közötti időben az egész hegyoldalt a Transylvania Bank vásárolta meg. Itt található az alkalikus-szénsavas Margit-forrás, a konyhasós-szénsavas Anna-forrás, a glaubersós Szilamér-forrás, a konyhasósvasas-kénes-szénsavas Transylvania-forrás és a lúgosszénsavas Imola-forrás. Még a 19. század végén itt létesült az első magyar szénsavpalackozó üzem, a barlangból idevezetett gázok felhasználásával. 1916-ban pusztult el, amikor a bevonuló románok felgyújtották.

Az I. világháború után a terület Románia fennhatósága alá került. Újságcikkek sokasága bizonyítja, hogy milyen mértékben bánkódott a kisebbségi sorsra ítélt magyarság, hogy a terület a különleges fürdőivel méltán lehetne világhírú, de attól messze elmarad [11]. Említésre méltó viszont, hogy 1938-ban egy román építész tervei szerint a régi kúraszálló átalakításával modern szanatóriumot építettek [9].

A visszacsatolás utáni helyzetről, a Csiszár-fürdő ezen hat év alatti változatlan múködéséról több újságcikk is beszámolt. Érthetó, hogy a Magyar Balneológiai Egyesület is értékelni kívánta szakmailag a visszatért fürdók helyzetét. Erdélyben 69 ilyenről volt szó. Helyszíni tanulmányozás céljából delegátusaik 1940. október 24-től november 16-ig tartózkodtak a terepen. Kunszt János, a Rudas-fürdő vezetô fóorvosa és Zselyonka László egyetemi tanársegéd (a Rheuma- és Fürdőkutató Intézet központjának otthont adó Kórtani Intézet munkatársa) összegzése így hangzott: „Beszámoló jelentés a keleti országrészekkel és Erdéllyel visszatért fürdők és ásványvizekról”, mely az egyesület Évkönyvében jelent meg [7]. Innen tudhatjuk meg azt is, hogy az 1895-ös gyógyfürdőintézmény korábban kibővített épületében ekkor már luxuskivitelú tüdőszanatórium múködött. Az egykori bédekker az idelátogatni kívánóknak pontos és részletes leírást szolgáltat a fürdőhelyról [12].

$\mathrm{Az}$ 1948-as romániai államosítás eredményeképpen - a szocialista országok ismert szokásrendje szerint - a környezeti adottságok kiaknázása voluntarista szemlélettel történt, és a nép számára turistaközponttá, üdülőhellyé való fejlesztésben testesedett meg. A pártvezetők részére magas komfortfokozatú villákat építettek, a turisták számára tömegszállásokat.

Ma a fentebb említett szálló, majd szanatórium helyén a nagystílú Grand Hotel Bálványos található, mely komplex kezelésekkel és borsos árakkal várja a neten jelentkező vendégeket. Állandó orvosi szolgálata van, meleg borvízfürdő, mofetta, fizikoterápiás és gyógyszeres kezelés áll a betegek rendelkezésére.

Más a helyzet a Csiszár-fürdővel. Fejlesztések nem voltak, inkább a lepusztulás jellemezte. A Romániában és Németországban nevelkedett, német dizájnegyetemet végzett, most román állampolgársággal is rendelkező Taierling testvérek, Johann és Péter - Csiszár Dénes ükunokái - 2005-ben telepedtek haza Németországból Kézdivásárhelyre azzal a céllal, hogy ne engedjék tovább pusztulni a jobb sorsra érdemes Csiszárfürdót, ükapjuk egykori birtokát, a hideg fürdőket [9], amelyeket aztán 2011-ben vissza is szereztek. Szisztematikus munkájuk következtében az éveken keresztül elhanyagolt állapotban levő Csiszár-fürdő az utóbbi esztendőkben lépésről lépésre szépült és gyarapodott. Pályázati támogatásokat szereztek, kalákamunkát szerveztek - még magyarországi diák résztvevő́knek is. Az alapító szellemének megfelelően a rendbe hozott medencéket a látogatók díjmentesen használhatják. Ám még sok idő kell ahhoz, hogy a telep teljesen újraépüljön, és visszanyerje egykori rangját.

Összegzésképpen elmondható: a három hegyoldalon elterülő bőséges forrásvidék jelentősen különbözik a többi régi és mai magyarországi, fürdő névvel illetett egységtől, mert 1) itt nem termálvizekről van szó, hanem a hideg vizes és ivókúrákra igencsak alkalmas forráskincsről, 2) a vadregényes, erdős hegyvidék egyben kitúnő turisztikai és üdülési célpontot kínál, és 3) a szerencsétlen történelmi fordulatok nem engedték meg a páratlan lehetőségek igazi kibontakozását. 125 évvel ezelőtt az akkori kor magas szintjén kezdődött el a fürdőtelep kialakítása, de az I. világháború befejezése utáni száz év fordulatai érthető módon nem kedveztek a fejlódésnek, fejlesztéseknek. Talán az utóbbi évtizedben nyílt egy reménysugár.

\section{Irodalom}

[1] Orbán B. Description of Székely Land. [A Székelyföld leírása.] Pest, 1868. [Hungarian]

[2] de Gerando A. Transylvania and the Transylvanian. Translated by Péter Gajda. [Erdély és az erdélyiek. Fordította Gajda Péter.] Kriterion, Kolozsvár, 2018. [Hungarian]

[3] Incze R, Jánosi Cs, Kisgyörgy Z, et al. Book about „mofettas” of Székely Land. [Székelyföldi mofettás könyv.] Háromszék Vármegye Kiadó, Sepsiszentgyörgy, 2017. [Hungarian] 
[4] Boleman I. The Waterbirth Handbook. [Fürdőtan.] Magyar Orvosi Könyvkiadó Társulat, Budapest, 1887. [Hungarian]

[5] Szilvásy J. Opening of Bálványos bath. [A Bálványos fürdő megnyitása.] Erdély 1895; IV: 186. [Hungarian]

[6] Papp S, Hankó V. (eds.) The mineral waters and bathplaces of Hungarian Empire. [A magyar birodalom ásványvizei és fürdőhelyei.] Magyar Balneológiai Egyesület kiadványa, Budapest, 1907. [Hungarian]

[7] The 1941 Yearbook of Hungarian Society of Balneology. Edited by Károly Moll. [Az Országos Balneológiai Egyesület 1941. évi évkönyve. Szerk. Moll Károly.] Budapest, 1942. [Hungarian]

[8] Great Lexicon of Révai. Third Volume. [Révai Nagy Lexikona. III. kötet.] Révai Testvérek Irodalmi Intézet Részvénytársaság, Budapest, 1911; p. 524. [Hungarian]
[9] Taierling J. Csiszár. One family-related bath. [A Csiszár családhoz kötött gyógyfürdő.] Magánkiadás, Guthenberg Druck, Mainz, 2007. [Hungarian]

[10] Erdős J. (ed.) Manual of Hungarian bathes. [Magyar Fürdőkalauz.] Engländer és Társa Könyvnyomtató Múhelyéből, Tata, 1911; pp. 35-36. [Hungarian]

[11] The lacked world renown. [Az elmaradt világhír.] (j. b.) Erdélyi Lapok 1935; 4(6). 1935. augusztus 25. [Hungarian]

[12] Reich Milton O. Tourist guide of Transylvania. [Erdély útikönyv.] Eggenberger-féle Könyvkereskedés, Budapest, 1942. [Hungarian]

(Gömör Béla dr., Budapest, Árpád fejedelem útja 7., 1023 e-mail: gomorbela@gmrbt.hu)

\section{"Exsilium patitur patriae qui se denegat." (Számkivetett, ki nem szenteli hazájának önmagát.)}

A cikk a Creative Commons Attribution 4.0 International License (https://creativecommons.org/licenses/by/4.0/) feltételei szerint publikált Open Access közlemény, melynek szellemében a cikk bármilyen médiumban szabadon felhasználható, megosztható és újraközölhetö, feltéve, hogy az eredeti szerző és a közlés helye, illetve a CC License linkje és az esetlegesen végrehajtott módositások feltüntetésre kerülnek. (SID_1) 